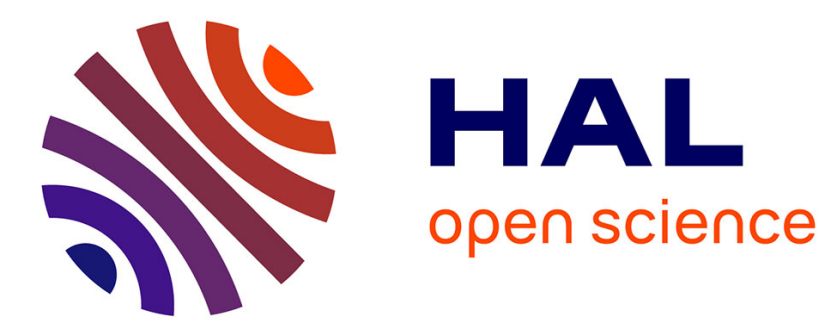

\title{
Space, politics, and the political
}

Mustafa Dikec

\section{To cite this version:}

Mustafa Dikec. Space, politics, and the political. Environment and Planning D: Society and Space, 1987, 10.1068/d364t. hal-01274375

\section{HAL Id: hal-01274375 \\ https://hal-enpc.archives-ouvertes.fr/hal-01274375}

Submitted on 15 Feb 2016

HAL is a multi-disciplinary open access archive for the deposit and dissemination of scientific research documents, whether they are published or not. The documents may come from teaching and research institutions in France or abroad, or from public or private research centers.
L'archive ouverte pluridisciplinaire HAL, est destinée au dépôt et à la diffusion de documents scientifiques de niveau recherche, publiés ou non, émanant des établissements d'enseignement et de recherche français ou étrangers, des laboratoires publics ou privés. 


\title{
Space, politics, and the political ${ }^{\dagger}$
}

\author{
Mustafa Dikeçণ \\ Middle East Technical University, Faculty of Architecture, Department of City and Regional \\ Planning, Inonu Bulvari, 06531 Ankara, Turkey; e-mail: mdikec@yahoo.com \\ Received 11 February 2003; in revised form 10 December 2003
}

\begin{abstract}
In this paper I offer a reading of Jacques Rancière's conceptualization of politics, and consider its implications for the links between space, politics, and the political. I provide an overview of Rancière's conceptualizations of 'the police', politics, and the political, and try to recover the spatiality of these notions. Based on this overview, the argument pursued in the paper is that space does not become political just by virtue of being full of power or competing interests. It becomes political by becoming the place where a wrong can be addressed and equality can be demonstrated. This definition makes space not only an integral element of the defining moment of the political, but an integral element of the disruption of the normalized order of domination as well.
\end{abstract}

\section{Introduction}

"Geography and politics", Gottmann wrote in 1980, "have long been in search of each other" (page 11). Debates in the literature suggest not only that they have found each other, but also that the encounter has instigated, notably in the last decade or so, a body of literature seeking to think space politically, and to think politics spatially. This is not to suggest that previous work on space was apolitical, nor to suggest that previous work on politics - at least in geography and urban studies - was aspatial. ${ }^{(1)}$ This is to suggest, however, that the issue of geography and politics has since become a significant issue orienting research and informing theoretical endeavors. More so, perhaps, in geography and urban studies as exemplified by the works, among many others, of Agnew (1987), Keith (1997), Massey (1993; 1995; 1999), Pile and Keith (1997), and Slater (2002). Although the response of political theorists to this encounter has been less marked,(2) some of the recent work suggests that its effects have not been one-sided (Bickford, 2000; Kohn, 2003; for an earlier example see Shapiro and Neubauer, 1989).

In this paper, which also is a product of this encounter, I engage with the issue of space and 'politics' through a reading of Jacques Rancière's theorization of politics. 'Politics' is qualified, for, as we will see, different understandings of politics - and of 'the political' - have different implications for the links between space and politics. Politics is commonly indicated by the presence of power or by the multiplicity of interests, power, and values. The political, in the first view, is "signaled by the presence of any human relations organized by power", whereas in the second it is "signaled by the distinct problematic of negotiating the powers and values of enduring collectivities" (Brown, 2002, page 569). The problem these understandings of the political pose for political

$\dagger$ Earlier versions of this paper were presented at Northwestern University's New Initiatives in Critical Theory Lecture Series in 2002 (Evanston, IL), and at the Fidelity to the Disagreement: Rancière and the Political Conference at Goldsmiths College in 2003 (London).

- Current address: Department of Geography, Faculty of Social Sciences, The Open University, Walton Hall, Milton Keynes MK7 6AA, England.

(1) See, for example, Johnston's (2001) review of the trajectory of political geography.

(2) Thus Massey (1995, page 284) wrote: "It is probably fair to say that political theory more broadly has sometimes been a rather aspatial enterprise: it has not thought its object of study in explicitly spatialized terms." 
theory - and this is the concern in Brown's article - is that, whereas the first view renders everything political, the second limits the scope of the political significantly.

An understanding of politics merely as power relations or, alternatively, as competing interests poses similar problems when the links between space and politics are considered. The first view renders space political because there are differential power relations in space that shape the production of space, and that, furthermore, sustain those power relations. The second view, as well, renders space political because there are groups with different and oftentimes conflicting interests trying to maximize their benefits. Space, in other words, is replete with already established and identifiable groups and/or institutions with peculiar and mostly contradictory interests. Neither of these understandings, I believe, effectively accounts for the political specificity of space. This is not to say that space is not imbued with power relations. Nor is it to imply that multiple and conflicting interests are irrelevant to the study of space and politics. It is to argue, however, that space does not become political just by virtue of being full of power, or by virtue of the contentious multiplicity of interests embedded in space. If it is simply power relations, which are everywhere, that make space political, there is little merit in stating that space, like everything else, is political. If it is the multiplicity of competing interests, why would space be of particular political importance? The first view renders everything - space included-political, whereas the second undermines the political salience and specificity of space. And both of them always already provide an answer to the question 'what is it that makes space political?' (for example, 'it is the power relations').

While not ignoring, let alone denying, the presence and significance of power relations and the contentious multiplicity of interests, I propose a change in focus, and argue, following Rancière, that space becomes political in that it becomes the polemical place where a wrong can be addressed and equality can be demonstrated. It becomes an integral element of the interruption of the 'natural' (or, better yet, naturalized) order of domination through the constitution of a place of encounter by those that have no part in that order. The political, in this account, is signaled by this encounter as a moment of interruption, and not by the mere presence of power relations and competing interests.

The rest of this paper is aimed at unpacking the arguments presented in the paragraph above. In the section below, I focus on Rancière's conceptualization of politics, and try to explicate the core concepts of his work. This is followed by a section in which I attempt to recover the spatiality of his thought, paying attention to his use of spatial terms and the role they play in his conceptualization of politics. In the final section I provide a discussion on space and the political.

\section{Police, politics, and democracy}

"police: government, organization."

Rey (1976, page 1339)

Foucault (1977) starts his discussion on space and power, or, better yet, on the connection between space and power, from two very specific examples: namely, the plague-stricken town and the Panopticon. These examples are particular forms of spatialization, of partitioning, and both depend on the 'true' identification of individuals or groups - with their 'true' names - and on keeping them in their 'proper' places. It is not, therefore, space per se that makes possible the efficient exercise of power (in the town or in the Panopticon), but a particular space, one that partitions, fixes, and remains immutable. It is on the basis of this spatial organization that effective government and effective exercise of power become possible. Thus the plague-stricken town becomes, in the words of Foucault (1977, page 198), "the utopia of the perfectly governed city" for its very spatial organization makes the true identification of individuals in their 
proper places possible. It is a spatial ordering that then becomes the basis - the perfect one-for government. This ordering, together with a logic of identification and a logic of the proper, has a name in Rancière's political thought - the police-and another spatial image, this time a fictive one, can be used to exemplify it.

The story is set in the City of Le Mans, where a bunch of unemployed people decide to create a political party. A certain Victor is elected president, and he is expected to present his views on politics at the next meeting of the party. Not having the slightest idea as to politics, Victor goes to a park in order to meditate, and sits next to an homeless person. Lucky Victor, the homeless person decides to give him a free tutorial on politics, and asks him to imagine a prison.

In this prison there are, unsurprisingly, prisoners. They have not done anything wrong. They were born in the prison, and they will stay there for the rest of their lives. It is pure chance, a whim of fate: there are those who were born in the prison, and those who were born outside of it - it is the natural order of things. One day the prisoners get frustrated, and start complaining. At that precise moment, the food stock in the prison expires. It is urgent to find food for the prisoners, otherwise they will all die. They have the right to elect a director. There is democracy in the prison. To begin, they elect a director from the Left, who thinks that the shortage of food in the prison is a major form of injustice. But things do not work very well with that director; people in the prison still do not have enough to eat. They, therefore, elect another director, from the Right this time, who proposes another solution to the problem. The prisoners, in fact, do not care much about the Left or Right as long as they have enough to eat. And the problem of food in the prison becomes the major issue in the agenda; people talk about nothing but the food problem in the prison. And this, the homeless person argues, is the fraud. Even if one day the problem of food in the prison is resolved, either by the Left or the Right, the situation will remain unchanged: they will have enough to eat, but they will still be in the prison. Politics, he concludes, is not about the food in the prison, but about the very prison. ${ }^{(3)}$

My aim is not to argue whether the homeless person is right or wrong, but simply to use the example he provides in order to make two introductory remarks. First, although Rancière shares a similar concern with Foucault-social domination-his politics is not centered around the notion of power, which, indeed, he criticizes. Whereas Foucault starts from a particular spatial organization to launch into a discussion on the links between space and power, Rancière, starting from a similar point with his notion of 'the police', focuses on the ways in which an established social order becomes the 'naturally given' basis for government. This basis endows some the authority to govern while leaving others as the governed or the dominated. Note how the particular spatial organization perceived to be naturally given provides a locus of enunciation peculiar to prisoners, turning their voices into noises: only noises that express complaints are heard from the prison, but not voices that question the established order of things, which would be the political moment. ${ }^{(4)}$ Prisoners thus remain forever the governed-either by the Left or the Right - and the actual spatial organization provides the given on the basis of which problems are defined, solutions proposed.

The second remark follows from the first. Although Rancière is mostly associated with the democratization of voice (see, for example, Deranty, 2003a, page 137), there is, I want to argue, a substantial spatial practice in his theorization of politics. The example of the prison is therefore chosen to introduce, if schematically, three notions that are central to Rancière's political thought - the police, politics, and democracy. The first notion,

(3) From Éric Rochant's 1997 movie Vive la République!

(4) "The political intervention", writes Rancière, "is that which designates as the manifestation of a logos what in the police order is seen only as noise" (1994, page 176). 
the police, refers to a defined whole with its partitioned spaces of those who live in the prison and those who live outside of it. The second notion, politics, is characterized by its absence in the way in which the problem of food in the prison is addressed as the prisoners remained confined to their peculiar locus of enunciation delineated by the given spatial organization. Democracy, the third one, is characterized in its most meager form - there is democracy in the prison, they have the right to elect a director-although much of what goes under democracy is often reduced to this conception. What is missing in the list is the notion of power. "Politics", writes Rancière at the outset of his "Ten theses on politics", "is not the exercise of power .... To identify politics with the exercise of, and struggle to possess, power is to do away with politics." He argues, furthermore, that conceiving politics "as a theory of power or as an investigation into the grounds of its legitimacy" is to "reduce the scope of politics as a mode of thinking" (2001, page 1). Politics implies a disruption of the order of the police, and its guiding principle is equality.

'The police' refers to an established social order of governance with everyone in their 'proper' place in the seemingly natural order of things. It is based on a partitioned spatial organization - "partition of the sensible" - whose principle is saturation - "the absence of a void and of a supplement" (2001, page 20). The connection to Laclau and Mouffe's (1985) concept of hegemony is clear. In their conceptualization, a totally sutured society, or, in other words, a total closure of the social, is impossible for there will always be a lack (or surplus), which the hegemonic practices try to fill in. And this lack or surplus makes hegemonic practices possible as hegemony presumes the open and incomplete quality of 'the social'. Hegemony, therefore, is always incomplete, and achieved in a context of antagonism: that is, through constant contestation. For Rancière, as well, the police is never a finished and immutable order, and the very lack or surplus in the police order is the constituting moment of the political, which also makes politics a permanent possibility as the 'givens' of a police order, from the viewpoint of politics, are never objective but always polemical.

Rancière defines the 'partition of the sensible' as "that system of sensible evidences that discloses at once the existence of a common [that is, the whole] and the partitions that define the respective places and parts in it" (2000a, page 12). From the viewpoint of the police, "society consists of groups dedicated to specific modes of action, in places where these occupations are exercised, in modes of being corresponding to these occupations and these places" (2001, page 21). Some places are places of noise, others of voice; work must be performed in certain times; public spaces are designed for the mingling of peaceful souls and not for the protestors of injustice, and so on. Even 'politics' has its proper place in the partitioned order of the police. This, however, is to confuse politics with the police, Rancière argues. What is generally referred to as politics, such as the organization of powers, the distribution of places and roles with its systems of legitimization, and even the procedures through which collectivities come together and reach a consensus, in fact, all fall under the category of the police as a system of governance. ${ }^{(5)}$ Such institutionalized practices belong to the police, and not to politics, which, as we will see below, cannot be institutionalized according to Rancière. The police is organization for government, which is achieved through the configuration of a perceptive field, through the symbolic constitution of the social, which becomes, from the viewpoint of the police, the basis for government. The police, then, is not simply a positive order, by which I mean an incontestable order that lends itself to 'objective' representation. It is not self-evident, and does not represent a singular 'reality'. It is perhaps exemplary in this sense that one of the first things that

(5) For a critique of the theoretical reduction of politics into mere governing and consensus-building systems see Honig (1993). 
the new minister of the interior in France proposed, known for his repressive measures and for his concern to 'restore the republican order', was to modify the periodicity of the publication of figures of delinquency, and to make them publicly available more frequently (Le Monde 2002).

The police may be understood to imply various ordering regimes, and it is not far from Walker's (1993, page 97) definition of 'regime' as having a status "somewhere between a concrete institution and a more or less invisible field of forces generated by structural determinations". Rancière's focus, however, is not merely on 'structures', and he uses the term 'police' in a broad sense to refer to "all the activities which create order by distributing places, names, functions" (1994, page 173).

Three points should be emphasized here. First, the plurality of activities in Rancière's definition is essential; otherwise the police would be merely a shorthand for totalitarianism. Second, the police-any police-order is contested and full of tension, and, although the police notion of the society is based on a principle of saturation, there is never a total closure. And, third, the police is not identical to 'state apparatus', and, thus, the term does not presuppose an opposition between state and society. "The distribution of places and roles that defines a police regime stems as much from the assumed spontaneity of social relations as from the rigidity of state functions" (1999, page 29). Every governing system specifies its police. Any hierarchical structure, then, might be seen as a police order:

"The police is thus first an order of bodies that defines the allocation of ways of doing, ways of being, and ways of saying, and sees that those bodies are assigned by name to a particular place and task; it is an order of the visible and the sayable that sees that a particular activity is visible and another is not, that this speech is understood as discourse and another as noise" (page 29).

Rancière uses the terms 'logic of identification' and 'logic of the proper' to characterize the organizational principles of the police. Whereas the former refers to the 'true' identification and counting of the parts of a whole to be governed, the latter requires that each part - everything and every-one - be properly placed (like Foucault's plaguestricken town representing perfect government). The essence of the police, then, is to identify a whole as the whole with each part in its proper place. The whole-the sum of the fully counted and properly placed parts - may be made of individuals enjoying their freedom. It may be made up of social groups with specific interests. It may also be made up of communities endowed with recognition of their identities and cultures. The police order is tolerant with this multiplicity as long as the parties are real parties, identified with the very individual or social group, and as long as they are placed properly.

But this counting of the parts and assignment of places can be challenged, which is the very possibility of politics. The essence of politics, Rancière argues, is to "disturb this arrangement by supplementing it with a part of the no-part identified with the community as a whole" (2001, page 21). Politics exists when the police order is disrupted, "when the natural order of domination is interrupted by the institution of a part of those who have no part" (1999, page 11) - the 'unaccounted for'. This definition immediately evokes a question: is Rancière's conception of politics based on a simple dichotomy between the 'accounted for' (those who have part in the right order of the police) and the 'unaccounted for' (those who have no part in it)? Isin (2002, page 277), for example, discerns this as a problem and asks (quoting Rancière, 1999, page 11): "But is becoming political that moment "when the natural order of domination is interrupted by the institution of a part of those who have no part'?" The problem for Isin is that, by "reproducing excluded/invisible and included/visible dichotomies", Rancière's politics fails to acknowledge that the visible and the invisible are integral 
parts of the same order, and fails, therefore, to question the very order of things and loses its subversive or transversal quality (Isin, 2002, page 277). Although I am in full agreement with him as to the perils of conceiving politics around such dichotomies, I would argue that this is quite a misleading interpretation of Rancière's politics, which, in fact, is very far from (re)producing dichotomies. Politics opposes the police, but that does not imply that politics is the business of an already existing part that is not counted in the police order. It is the disruption of the police order-the sum of the fully counted, rightly named, and properly placed parts - by a part that has no part in this particular counting, naming, and partitioning. The police order implies a saturated order, where every-one is counted, everything is partitioned. So maybe a more stimulating question would be the following: if every-one is counted, where is the unaccounted for; where does it come from? If space is partitioned in its entirety by the police, where does politics stem from? What, in other words, is the democratic theme in Rancière that would institute politics as a disruption of the police order?

The answer to this question may be stated in a sentence: the whole is more than the sum of its parts. The whole in question is a whole defined as the whole by the police order. Rancière's 'unaccounted for' does not mean that there exists a hidden bunch of political subjects to turn up and disrupt the police order. Every-body is counted. The unaccounted for is at once nowhere and everywhere. The subject of democracy, and thus of politics, is 'the people', not understood as "the collection of members in a community, or the laboring classes of the population", but as the "power of the one more, the power of anyone" (1995a, page 64, emphasis in original). As Rancière maintains, "There is no constant body of the demos that would support democratic pronouncements" (2000b, page 19). From the viewpoint of the police, 'the people' (demos) is identical to the sum of the parts, and can be identified with a race, or population, or professional categories, or simply with the sum of those casting their votes at the proper time, in the proper place, in the proper way, under proper names. This "attempt to find a direct correspondence between the notion of 'the people' and that of 'the population', defined as an object that can be completely broken down into given empirical categories", for Rancière, signals the collapse of politics (1997, page 31). 'The people' is not identified with a political category that corresponds to countable parts. 'The people' is the name of anyone, and no one in particular.

We saw an interesting example of the contested nature of the notion of 'the people' during the debates that followed the first round of presidential elections in France in April 2002. Le Pen's party, the National Front, which is the major far-Right, xenophobic political party in France, was able to make it to the second round, defeating the Socialist Party and becoming the second majority party in the country. Many people immediately took to the streets after the results were announced, protesting the National Front and carrying signs that read 'We are all children of immigrants' obviously an impossible identification, a 'wrong' name. Now for those who were not delighted with the results, 'the people' consisted of the very protestors on the streets, articulated spatially regardless of their age, origins, or the social groups they belong to. For the members of the National Front, however, they were simply disrespectful individuals for they did not 'respect the vote of "the people". 'The people', on this account, was the sum of voting individuals. 'The people', on the other, was, in fact, on the streets.

Similarly, a political subject, in Rancière's account, does not refer to a group of interests or ideas, and the identification of the political community with the social body is an identification that cancels politics. Political subjects and politics exist insofar as a disjunction between political subjectivity and social groups exists. Here, an example provided by Rancière may be used for illustrative purposes: namely, the increased 
xenophobic reactions against immigrants in France, which he sees as "the collapse of emancipatory politics as a politics of the other" (1995a, page 69). There are not more immigrants in France compared with twenty years ago, but now immigrants have lost their political name and are reduced to a social or ethnic category:

"The difference is this: twenty years ago the 'immigrant' had an other name; they were workers or proletarians. In the meantime, this name has been lost as a political name. They retained their 'own' name, and an other that has no other name becomes the object of fear and rejection" (1995a, page 70, emphasis in original).

Another example can be provided in order to make arguments more concrete, to argue further that the opposition between the police and politics is not based on a simple dichotomy of 'the included' and 'the excluded', and to discern the democratic theme in Rancière's politics: the political implications of the widespread use of the notion of 'exclusion', not only in France but in most of Western Europe as well (see, for example, Percy-Smith, 2000). Since the early 1990s, in France at least, public policy discourse and practice has been dominated by this notion. In a situation of growing inequalities, there is talk no longer about exploitation, uneven development, and so on, but of 'exclusion' and 'the excluded'. Structural dynamics that produce and reproduce inequalities disappear from the policy agenda, and the name of the problem becomes 'exclusion'. Hence not only is the 'problem' separated from its structural dynamics, but also a certain idea of society is evoked, where 'the included' are doing just fine (Levitas, 1996). The 'whole' that orients public policy and action is thus partitioned; there are the excluded and the included.

Politically, however, identifying 'the excluded' as the excluded is already to include 'them' in the whole; nothing escapes the police, especially 'the excluded'. And, once the excluded are identified as such, the possibility of politics is canceled out at the outset; there is room merely for modifications in the police order, motivated either by a moral effort to 'include the excluded', or by a concern with the security of 'the included' threatened by the outside-all coming from above, from the Left or the Right, as in the example provided by Victor's homeless friend. The inclusion of the excluded is about alterations in the police order, and is not a political issue precisely because there already exists a partitioning. The democratic theme is not that the police order can be all-inclusive. For Rancière, this is not possible; every order will have its unaccounted for, its remainders. This raises a particular form of claim about democracy: the only place one finds the unaccounted for is in the emergence of a political articulation, at a particular time and space, an emergence that becomes the claim of the unaccounted for to redefine the whole and to speak for this whole, which both is and is not yet. This is the democratic theme: making a claim to be the whole, not to be included in the whole. In other words, the democratic theme precisely is not the inclusion of the excluded; it is the posture of the redefinition of the whole through the disruption of the police order by the institution of politics. Such a posture toward democracy and politics makes necessary the following three features of politics and the police.

First, politics, for Rancière, cannot be institutionalized; it has no institutional determination. Formally allowing space for dissent, through the law for example, is useful in itself but is not a condition of politics. Politics is a call of the demos for a new institutionalization. Second, the police has to be nonpejorative as any redefinition of the whole will inevitably lead to the reconstitution of another police order, to the sedimentation of another partition of the perceptible- 'better' or 'worse'. The police, in other words, is not intrinsically 'bad'. There are, however, practices of policing, and, although the police may be sweet and kind, it is still the opposite of politics. This premise, however, evokes the question as to whether an a priori knowledge that another police order will eventually be established exists. It might be possible - theoretically, 
at least - to argue that there is nothing to guarantee a priori the constitution of a new police order after the disruption of politics. Such a position, however, would be quite difficult, if not impossible, to maintain once the police is understood in the sense Rancière uses the term: not as a transcendental order, but as any hierarchical structure. This 'any' is an important one, and politics serves as an important reminder of the established hierarchies of the order-of any order. There is nothing-and this is one of the points of divergence between Derrida and Rancière-messianic about politics; politics, for Rancière, is a permanent possibility.

And, third, there is no way to be able to say where politics might emerge from. The unaccounted for cannot be identified before disrupting the police order through politics. The unaccounted for come as a surplus to the saturated and partitioned whole. Politics is an emergence-a rare one.

What, then, characterizes this rare, yet permanently possible, emergence? What are its essential features? An example offered by Rancière might be helpful here, that of the retreat of Roman plebeians on Aventine Hill. This, for Rancière, is not a revolt caused by poverty and anger, but a conflict over who has the status of a speaking being to make a claim on the whole of the community. Unlike the revolting Scythian slaves, who constitute themselves as warriors equal to other warriors, but who eventually give up the fight when confronted not with spear and bow but with horsewhips - when treated, in other words, not as warriors but as slaves - the Roman plebeians "establish another order, another partition of the perceptible" as "speaking beings sharing the same properties as those who deny them these" (1999, page 24). The conflict, therefore, is not about assessing interests and entitlements between parties; it is, first of all, a conflict concerning "the existence of parties as parties and the existence of a relationship that constitutes them as such" (page 26). ${ }^{(6)}$

For Rancière, the story of the Roman plebeians represents an instance of the properly political. Let me try to discern some characteristics that render this act as politics proper in Rancière's scheme. First, the act of the plebeians is not a simple assertion of an identity, an identity given by the existing order ('Plebeians should be treated with more respect and should have better conditions of living'). What the plebeians do is first to reject the 'right' name given to them by the police order, and, second, to give themselves a name, a 'wrong' name, an impossible identification from the viewpoint of the police (in the words of the storyteller, becoming 'men' from being 'mortals'). There is, therefore, a disidentification followed by an impossible, a 'wrong' identification. Third, they constitute an order with another conception of the whole ('Look, in this new world we envision, there is no such distinction between plebeians and patricians as far as the equality of speaking beings goes'). And, in so doing, they construct a space, a polemical common space for addressing a wrong and demonstrating the equality of anyone with anyone, a common space in which two worlds - and two opposing logics, the logic of the police (true identification and proper placement) and the logic of equality-exist simultaneously. This is a common space where one finds together the patricians, deprived of their superiority and insolence that turned the plebeians' voices into noises, denying discourse to them, and the plebeians, freed from their imposed inferiority that denied them the audacity to identify themselves with the whole of the community and not as a part-well-identified and clearly demarcated - that has no part in it. This coexistence, this demonstration of two worlds

(6) Such an argument poses serious challenges to highly rational and procedural positions. Rancière criticizes Habermas, for example, for he presupposes "that both the interlocutors and the objects about which they speak are preconstituted". According to Rancière, however, "there can be political exchange only when there is not such a preestablished agreement-not only, that is, regarding the objects of debate but also regarding the status of the speakers themselves" (2000c, page 116). 
in one that "holds equality and its absence together" (1999, page 89), makes the handling of a wrong and the verification of equality possible, and is a crucial condition for politics to occur.

Another notion should be explicated here- 'wrong'. Politics, Rancière argues, "is a function of the fact that a wrong exists, an injustice that needs to be addressed" (1995b, page 97). This wrong, however, is not a juridical wrong (otherwise it would be resolved by the institutionalized practices of the police) or an infinite debt, but a form of injustice experienced by the members of a community-community understood in a large sense. It follows from the 'twistedness' - or 'wrungness', as Deranty refers to it (2003a) - of the established social order. Although the police order does not deny equality (equals as citizens, equals as human beings, and so on), it nevertheless produces instances of inequality that call for the institution of polemical scenes for the verification of equality: for the handling of a wrong, in other words, through the institution of politics, guided by the supposition that everyone is equal. Rancière plays on the word 'wrong' (le tort), which comes from the verb tordre, to twist, and maintains that, although the police does not deny equality, it wrongs equality (1995a). As Deranty (2003a, pages 143 - 144) notes, this has a strong resemblance to Hegel's master - servant relationship (1977 [1807]). Masters insist that they be recognized as masters by those they dominate, this but recognition of inequality is possible only once the masters themselves recognize the very ability of the dominated to recognize. Equality exists, therefore, not as an a priori given, but as an assumption to be constantly verified and demonstrated. "[T]he only universal in politics", writes Rancière (1995a, page 65), "is equality".

The political instant, as Rancière's example of the Roman plebeians suggests, consists in the encounter between the police logic and the logic of equality through the constitution of a common space where a wrong can be addressed and equality can be demonstrated. The definition of the political instant as the meeting of these two logics, I shall argue in the concluding section, has important implications for the links between space and politics. Before doing so, however, I shall discern the different spatial premises underlying the police and politics, for such a reading with a focus on space provides not only further insight into these two notions but also a threshold to launch into the section on space and politics.

\section{Spaces of the police, spaces of politics}

The spatiality of the police is perhaps best described by Laclau, who equates the police with politics, and reaches the following conclusion: "Politics and space are antinomic terms. Politics only exist insofar as the spatial eludes us" (1990, page 68). An eloquent critique of this assertion is provided by Massey (1993), who argues that it is Laclau's particular conception of space that utterly strips space of any political possibility. I would argue, furthermore, that the conception of space Laclau provides belongs to the police, and not to politics.

Space, in Laclau's conceptualization, is constitutive of the social insofar as it fixes meaning and serves as a means of closure. Whereas space is devoid of politics, the temporal carries, contrary to the spatial, the genuine possibility of politics. This particular conception of space brings to mind Foucault's remarks on the devaluation of space. "Did it start with Bergson, or before?", Foucault asks: "Space was treated as the dead, the fixed, the undialectical, the immobile. Time, on the contrary, was richness, fecundity, life, dialectic" (1980, page 70). There exists little or no political possibilities on the realm of the spatial for Laclau, for it is the realm of statis, of fixation and closure, lacking the necessary (temporal) dynamics for any possibility of politics. Spatial closure signals the end of political possibilities for Laclau. Spatial closure, however, is not absolute, and space, as Massey (1999, page 284) maintains: "can never be that completed simultaneity 
in which all interconnections have been established .... There are always loose ends in space." Massey's argument is that, by conceptualizing space merely as 'completed simultaneity' with immutable interconnections and juxtapositions, Laclau neglects the dynamic, transformative, conflictual, and thus political possibilities offered by space. This might have to do with the example chosen by Laclau to advance his argument. The example is Wolin's reading of Plato's idea of city and community:

"In Plato's scheme, there was no power to share; what was sharable was the Form of the Good written into the structure of the community. The results of this line of argument were two-fold: the idea of citizenship was severed from the idea of meaningful participation in the making of political decisions; and the idea of the political community, that is, a community that seeks to resolve its internal conflicts through political methods, is replaced by the idea of the virtuous community devoid of conflict and, therefore, devoid of 'politics'. Plato did not deny that each member of the community, no matter how humble his contribution, had a right to share the benefits of the community; what he did deny was that this contribution could be erected into a claim to share in political decision-making" (1960, page 57).

Laclau then interprets Plato's scheme as leaving no room for 'dislocation', which, for Laclau, implies politics for it is 'pure temporality' (1990, pages 39 and 65). Plato's scheme cancels out dislocation, and therefore politics, for it is utterly spatial:

"This communitarian schema was so absolutely spatial that nothing in it could be left to the discretion of a temporal intrusion-dislocation. Everything, including the number of the community's inhabitants, had to be mastered by a simultaneity in which being and knowledge entered into strict correspondence (page 70, emphasis added).

Now the example chosen as the ultimate annulment of politics by space raises a few problems, as whether Plato conceived his ideal city to foster the disruption of politics or to cancel it out entirely is an issue open to debate. Plato was a philosopher not of politics, but of political stability, of perfect governance without the disruption of politics, based on a definite division between an active ruling group and a passive community with everyone in their 'proper' place. It should not, therefore, be surprising that he employed a particular spatial conceptualization, not because he wanted to address the problem of politics, but precisely because, as Laclau himself admits, he wanted to address (indeed, to eliminate), the problem of politics. If Plato has something to teach us about space, it is space as emptiness, as statis, a fixed and inert 'container' of human life geometrically divisible into discrete and mutually exclusive parts. In this conceptualization, as Laclau observes in the passage above, space-static, partitioned and partitioning - becomes a means of mastery, providing an immutable and exclusive system of partitioning as the basis of and for (perfect) government. With this conceptualization of space, with this Platonic urge to put things in their proper place through spatial closure, the polis is reduced to the police, whose essence is to constrain the transformative power of space.

But the polis (understood not through nostalgic allusions, but simply as a form of political association and organization with an inherently spatial dimension) gave rise not only to police, but to politics as well, and this, I believe, is the dimension that is missing from Laclau's scheme. Laclau's argument merits attention for it makes clear that the links between space and politics cannot be taken for granted. Indeed, space, more often than not, appears as a means of control, governance, and domination, and not necessarily as a means of politics, if by politics one understands more than the workings of political parties and institutions of government. But space could also be the organizing principle and site of democratic pronouncements (politics), and not merely an effective means of political stability and perfect governance without disruption 
(police). Space is neither naturally given nor immutable, but rather is a product of interrelations always in the making, and never "a totally coherent and interrelated system of interconnections", and, thus, is both disrupted and a source of disruption (Massey, 1999, page 280). It is this transformative power of space that is neglected in Laclau's reduction of Plato's polis to police, devoid of politics. Space implies coexistence, but coexistence does not necessarily mean 'completed simultaneity' with immutable interconnections and juxtapositions (Massey, 1999). So, in a sense, Laclau is right when he says that "Politics only exist insofar as the spatial eludes us", but the 'spatial' here is a particular one, and this particular conception of the spatial belongs not to politics but to the police. Whereas Plato's conception of community, for Laclau, represents the ultimate cancellation of politics through space, for Rancière it represents "the total elimination of politics as a specific activity" (1999, page 70) through the institution of a police order, through, in other words, the delimitation or elimination of democratic spaces, or, better yet, through the saturation of the community that allows for no openings that could possibly become sites of democratic pronouncements.

The space of the police is space as emptiness, as statis, a fixed and inert 'container' geometrically divisible into discrete and mutually exclusive parts, the sum of which gives the count that is equal to the 'whole' to be governed. It is, in spatial terms, the embodiment of geometrical reason, of administrative rationality, inviolable and sharply partitioned. It spatially articulates identities (logic of identification) and distributes them to their proper places (logic of the proper), and thus displaces, through placement, the disruption of politics through an exhaustive ordering of space.

And yet, politics occurs - if rarely - as Rancière's scheme suggests. Space is used to construct locally the place of the universal (that is, equality), that polemical place where a wrong can be addressed and equality can be demonstrated. Politics takes place, in other words. Therefore, spatialization does not necessarily imply the cancellation of politics, and becomes the very condition of politics precisely because it constitutes an integral element of the disruption of the natural order of domination. Rancière writes (2001, page 22, emphasis added): "The principal function of politics is the configuration of its proper space. It is to disclose the world of its subjects and its operations. The essence of politics is the manifestation of dissensus, as the presence of two worlds in one." Whereas, for Laclau, the possibility of politics is undermined by the fixity of space, Rancière's politics is made possible by a multiplicity of political subjects configuring, transforming, appropriating space for the manifestation of dissensus, for the coexistence of two worlds in one, becoming political subjects in and through space. Closure by space is the end of politics for Laclau. Disclosure in and through space, for Rancière, makes politics possible. The conceptualization Laclau provides overlooks, in my view, the possibility that political subjects can constitute themselves spatially, open new discursive spaces of political debate, transform the (proper) space of circulation into a space of parade, or transform the (proper) space of work into a space in which a political capacity can be demonstrated, rather than simply succeeding into pregiven structures when the Time comes. Space, for Laclau, can merely be the 'container' of politics, but not its institution and organizing principle.

Two important features of Rancière's conceptualization of the police and politics emerge from this reading. The first one is that the police and politics are enmeshed. In other words, the spaces of politics are enmeshed with the space of the police. If politics puts the police ordering of space to an egalitarian test, then politics is possible not despite the police, but because of it. "Politics acts on the police", Rancière (1999, page 33) writes, "It acts in the places and with the words that are common to both, even if it means reshaping those places and changing the status of those words." Politics proper acts on the police space, from the police space, and 
through the police space. It, however, acts not in the police space, but inbetween spaces that are not determined by the police, that have no place in the police space. ${ }^{(7)}$ Politics consists in a reconfiguration, in "a series of actions that reconfigure the space where parties, parts, or lack of any parts have been defined" (1999, page 30; emphasis added).

"Political activity is whatever shifts a body from the place assigned to it or changes a place's [function]. ${ }^{(8)}$ It makes visible what had no business being seen, and makes heard a discourse where once there was only place for noise; it makes understood as discourse what was once only heard as noise" (page 30).

The second feature has to do with Rancière's use of spatial terms. Although Rancière does not write about space, his writings on politics are pervaded with spatial terms. Why, then, does Rancière employ spatial terms? What purpose do they serve? Which qualities of space - to render it 'political' - are emphasized by Rancière so that politics remain a permanent possibility despite the determination of space by the police?

By employing spatial terms, Rancière emphasizes, as I suggested above, the enmeshing of the police and politics, avoiding, therefore, a clear-cut separation of the police and politics. This spatial interpretation might also be used as a criterion to distinguish between 'better' and 'worse' orders of police-a point on which his work offers little elaboration. The challenge for the 'better' police would imply resisting the Platonic urge, and keeping open the possibility of the formation of new spaces of politics.

This enmeshing, however, requires some form of distinction between the spaces of the police and of politics, and I believe this is why Rancière deliberately distinguishes between three spatial terms in his writings: espace, lieu, and place (although in English translations we have space for espace, and place for both lieu and place). When Rancière is writing about the police, he uses place to emphasize the logic of the proper. Only once, if I am correct, he uses 'space' when writing about the police, but qualifies it with the adjective 'determined'.(9) When writing about politics, however, he uses either lieu or espace, both of which, in relation to the French place, carry a more 'neutral', less determined, and more immediately geographical quality. Place implies the idea of the 'proper', ${ }^{(10)}$ some form of ordering, hierarchy, and fixation, ${ }^{(1)}$ whereas lieu and espace do not necessarily imply such qualities. Therefore, the 'place' that translates place, and the place that translates lieu do not imply the same thing. Here I find the definitions offered by de Certeau (1984) useful. He distinguishes between place (lieu) and space (espace) in a way that is similar to the distinction I want to emphasize between the proper places of the police and the spaces of politics. "A place (lieu)", he writes,

"is the order (of whatever kind) in accord with which elements are distributed in relationships of coexistence. It thus excludes the possibility of two things being in the same location (place). The law of the 'proper' rules in the place: the elements taken into consideration are beside one another, each situated in its own 'proper' and distinct location, a location it defines. A place is thus an instantaneous

(7) This is what Rancière refers to as "intervals of [political] subjectification": "intervals constructed between identities, between spaces [lieux] and places [places]. Political being-together is a being-between: between identities, between worlds" (1999, page 137).

(8) In the English translation, this part is given as "a place's destination". 'Function', I believe, would be a more appropriate translation, which is what is implied in the phrase "la destination d'un lieu" (see Rancière, 1995c, page 53).

(9) "As conceived by 'the police', society is a totality comprised of groups performing specific functions and occupying determined spaces" (Rancière, 2000c, page 124).

(10) Like in 'chacun à sa place' (each to his or her proper place, the place where he or she belongs), or 'savoir rester à sa place' (to know one's place).

(11) The French 'place' comes from the Latin 'platea'. The more technical term 'platée' is also derived from platea, and means 'foundation of a building'. 
configuration of positions. It implies an indication of stability" (de Certeau, 1984, page 117, emphasis in original).

Space (espace), on the other hand,

"is composed of intersections of mobile elements. It is in a sense actuated by the ensemble of movements deployed within it. Space occurs as the effect produced by the operations that orient it, situate it, temporalize it, and make it function in a polyvalent unity of conflictual programs or contractual proximities .... In contradistinction to place, it has thus none of the univocity or stability of a 'proper" (page 117).

Although de Certeau's distinction effectively defines the places ( place) of the police, it still seems necessary to make a distinction between space (espace) and place (lieu). We could consider space as a relatively consolidated product - always in the making-of various boundary-making practices, through and/or in relation to which one could identify oneself. The boundaries may be rigid or porous. However, the consolidated boundaries still form a relatively stable domain of individual and collective experience. Place-again, always in the making - implies more investment (discursive, through practices, and so on) in and inside the boundaries, and suggests a relatively more stable and more clearly defined domain of experience. The dynamic quality of space (and of place) suggests the impossibility of a total closure, or, in other words, the possibility of opening, transformation, and appropriation. Politics, thus, remains a permanent possibility, the established order of the police with every-one in their proper place notwithstanding. Rancière writes that politics "has no "proper' place [lieu propre]"-otherwise it would not be politics proper- "nor does it possess any 'natural' subjects" (2001, page 25). This connects to a related issue, which has to do with the formation of political subjectivities. In a similar way to the antiessentialist approach of Laclau and Mouffe (1985), but through a different medium (that is, space), Rancière wants to free politics from the ontological centrality — or even necessity — of already established identities. He writes:

"A political subject is not a group that 'becomes aware' of itself, finds it voice, imposes its weight on society. It is an operator that connects and disconnects different areas, regions, identities, functions, and capacities existing in the configuration of a given experience" (1999, page 40).

"Any subjectification is a disidentification, removal from the naturalness of a place [ place], the opening up of a subject space [espace] where anyone can be counted since it is the space [espace] where those of no account are counted, where a connection is made between having a part and having no part" (page 36, emphasis added).

Space, then, carries a 'neutral' - that is, not determined by the police-yet generative and transformative quality, which is potentially emancipatory. It generates a peculiar relationship to the order of things as a medium and organizing principle of politics, and plays a part in the articulation of political subjectivities. Space thus becomes an integral element of the disruption of the 'natural' order of domination as the place where a wrong can be addressed and equality be demonstrated. It becomes, in short, political.

\section{Space, politics, and the political}

Mouffe proposes the following distinction between 'the political' (le politique) and 'politics' (la politique):

"By 'the political', I refer to the dimension of antagonism that is inherent in all human society, antagonism that ... can take many different forms and can emerge in diverse social relations. 'Politics' refers to the ensemble of practices, discourses, and institutions which seek to establish a certain order and to organize human coexistence in conditions which are always potentially conflictual because they are affected by the dimension of "the political" " (1995, pages 262-263). 
'The political', therefore, cannot be restricted to forms of institutionalized practices even if such practices may formally form the sphere of 'politics'. There is, indeed, a whole body of literature that makes such a distinction, and insists that the political cannot be reduced to politics (see, among others, Lacoue-Labarthe and Nancy, 1997; Lefort, 1988; Nancy, 1988; 1991; 2001; for an analysis of the debates see Critchley, 1992). As a moment of openness and undecidability, the political, rather than remaining confined to established practices of government, implies the calling into question of the very structuring principles of the established order (Žižek, 1991). As such, it is "a function of episodic encounters" (Shapiro, 2002, page 232), and is not institutionally determined. It does not, in other words, have a proper place.

Rancière shares a similar concern with this body of scholars ${ }^{(12)}$ - that the political cannot be reduced to politics - but employs a different terminology. What is referred to as 'politics' in this literature becomes 'the police' (la police), and what is referred to as 'the political' (le politique) becomes 'politics' (la politique) in Rancière's scheme. He reserves the term 'the political' (le politique) to designate the place for the defining moment of politics: that is, the encounter between the police logic and the logic of equality, between, in other words, a process of governing and a process of political subjectivization guided by the logic of equality, attempting to verify the equality of anyone with anyone. The political, in Rancière's political thought, indicates the place of this encounter as the "field [le terrain] for the encounter between emancipation and the police in the handling of a wrong" (1995a, page 64). ${ }^{(13)}$ Used as a term to mediate between la police and la politique, le politique makes politics possible. Indeed, as Deranty (2003a, page 144) observes, "If we only had the head-on opposition between la police and la politique, the possibility of political activity and political thinking would be nonexistent." The political makes politics possible, and indicates its taking place through the construction of a common space where the two logics meet.

This specific definition of the political moment as the encounter between the police order and the equality principle accounts for Rancière's skepticism towards the notion of power. In order to consider the political moment as the encounter between these two logics, he argues, the concept of power should be dismissed, for it "assert[s] in advance a smooth connection between them" (1999, page 32). Rancière's point here is to discern the specificity of the political by avoiding the argument that 'everything is political' as power relations are at work everywhere, which comes to saying that nothing is. He writes (page 32, emphasis added):

"So while it is important to show, as Michel Foucault has done magnificently, that the police order extends well beyond its specialized institutions and techniques, it is equally important to say that nothing is political in itself merely because power relationships are at work in it. For a thing to be political, it must give rise to a meeting of police logic and egalitarian logic that is never set up in advance."

It must, in other words, take place by configuring the common space of encounter. "Politics", Rancière argues (page 42), "is not made up of power relationships; it is made up of relationships between worlds". It is important, therefore, to construct a common polemical space, for only the meeting of these two logics makes possible the redefinition of the whole; only in this way might it be possible to disrupt the 'right' order of the police rather than merely to bring about alterations within the already existing order with its established forms of identification and partitioning.

(12) The list, of course, is not exhaustive. Deranty (2003b), for example, suggests that Rancière's political thought can be seen within a strand of political theory he refers to as 'ontology of the political', with such authors as Agamben, Badiou, and Nancy.

(13) The term 'la police' was originally translated as 'policy' in this chapter, which I changed to 'the police' (see Rancière, 1998). Later translations, however, use the term 'the police'. 
"So nothing is political in itself. But anything may become political if it gives rise to a meeting of these two logics [that is, police logic and the logic of equality]. The same thing - an election, a strike, a demonstration - can give rise to politics or not give rise to politics. A strike is not political when it calls for reforms rather than a better deal or when it attacks the relationships of authority rather than the inadequacy of wages. It is political when it reconfigures the relationships that determine the workplace in its relation to the community. The domestic household has been turned into a political space not through the simple fact that power relationships are at work in it but because it was the subject of argument in a dispute over the capacity of women in the community" (Rancière, 1999, pages $32-33$ ).

This conceptualization of the political has close resonances with that of Nancy, one of the few contemporary authors who is referred to in Rancière's work. Nancy, too, makes a distinction between 'politics' and 'the political'. Politics refers to the play of power and interests in processes of governance concerning the community (Rancière's 'the police'). The political, on the other hand, cannot be reduced to governmental rationality. Nor can it be reduced to a "sociotechnical element of forces and needs" (Nancy, 1991, page 40). "[The political] does not primarily consist in the composition and dynamics of power ..., but in the opening of a space" (1988, page 104). The political for Nancy, as for Rancière, implies inauguration of space in and through which the very structuring principles of the community, which is always in the making, are put into question. This space, however, is not "just the locus of power relations", but "the place where community as such is brought into play" (1991, page xxxvii). It is a place of 'being-in-common', a notion that Nancy uses to imply that there are no definitive bases for attachment, in other words, no proper places that definitively secure identities. The space inaugurated by the political is itself inaugural where freedom is exercised-for Nancy - and where a wrong is addressed and equality demonstrated - for Rancière.

This conceptualization of politics and the political has a substantial spatial dimension, which implies forms of political subjectivization in and through space. This is also indicated in Rancière's definition of the subject of politics, 'the people' (demos), which, as the etymological origin of the notion suggests, implies spatially articulated forms of political subjectification. Benveniste (1969) writes that it was originally a concept at once territorial and political, implying a common social condition and not bonds created through kinship or formal political belonging. The root*dem- is a root signifying 'to build' and 'house' (which gives rise to the Latin domus, 'house'). The Greek words demios ('belonging to the people') and demos are derived from this root (see Casey, 1997, pages 349 and 356). This implies that politics, despite the possible perils of spatial closure, needs to define its spaces. Forms of political engagement can mobilize from and make use of organizational spaces, spaces of categorization, representations of space, and physical spaces - in short, various forms of boundary-making and maintenance practices - for inaugurating spaces for politics. There is, in other words, a need for relatively stable formations for democratic pronouncements. Space, then, becomes the place-if only transiently - where a wrong can be addressed and equality be demonstrated.(14) But Rancière wants to keep the spaces of politics open and free from predetermination. Hence his insistence that "There is no constant body of the demos that would support democratic pronouncements" (2000b, page 19), and his skepticism towards the notion of utopia, which would imply a univocal configuration of sensible evidences (2000a, pages 64-65). Politics implies an ongoing confrontation,

(14) That said, it is important to note that place-making does not inherently imply politics; it could, indeed, work against it, as in fascist regimes and various forms of fundamentalism (Euben, 2002; Kohn, 2003). 
not a definite project that starts and comes to an end once an ideal space (and time) is constituted. It implies multiplicities of space and time. It is thus neither utopian nor messianic, but episodic.

This reading of Rancière suggests new ways of conceptualizing the links between space, politics, and the political. Space is pertinent to the police because identificatory distribution (naming, fixing in space, defining a proper place) is an essential component of government. The police is an attempt to make the political order neatly correspond with the spatial order. Space is pertinent to politics because it is this very distribution, this very partitioning of space, that is put into question. The police and politics, from this point of view, are inherently spatial for they are both concerned with distributions - of activities, authorities, functions, names, individuals or groups, and places. Such distributions define 'legitimate' interlocutors, make sensible certain issues while making others imperceptible, and distinguish voices from noises. Politics acts on such distributions normalized by regimes of governance. It is about the givensalways polemical and never objective - of a situation, not about alterations within an already established order. It is, in other words, about the established order of things, including established practices of identification, guided by two assumptions: the sheer contingency of the order - of any order - and the equality of anyone with anyone. Politics implies a disruption of the established order through a reconfiguration of the system of partitioning.

And space is political as an integral part in this for it becomes the place where the order of the police is put to an egalitarian test. The political indicates that space, governmental ordering of which makes the police possible, may become the place where the very structuring principles of the order are put into question, indeed undone. Space becomes the place from which to become actors of democratic pronouncements.

Acknowledgements. I am grateful to Benjamin Arditi, Claire Hancock, Doreen Massey, Kirstie McClure, Michael Shapiro, and the anonymous referees of Society and Space for comments and suggestions. All responsibility, it goes without saying, remains mine.

\section{References}

Agnew J, 1987 Place and Politics: The Geographical Mediation of State and Society (Allen and Unwin, Boston, MA)

Benveniste E, 1969 Le Vocabulaire des Institutions Indo-européennes. Tome 2: Pouvoir, Droit, Religion [The vocabulary of Indo-European institutions. Volume 2: power, law, religion] (Éditions de Minuit, Paris)

Bickford S, 2000, "Constructing inequality: city spaces and the architecture of citizenship" Political Theory $28355-376$

Brown W, 2002, "At the edge" Political Theory 30 556-576

Casey E, 1997 The Fate of Place: A Philosophical History (University of California Press, Berkeley, CA)

Critchley S, 1992 The Ethics of Deconstruction: Derrida and Levinas (Blackwell, Oxford)

de Certeau M, 1984 The Practice of Everyday Life (University of California Press, Berkeley, CA)

Deranty J-P, 2003a, "Jacques Rancière's contribution to the ethics of recognition" Political Theory $31136-156$

Deranty J-P, 2003b, "Rancière and contemporary political ontology" Theory and Event 6(4), http://muse.jhu.edu/journals/theory_and_event/toc/archive.html\#6.4

Euben J P, 2002, "The polis, globalization, and the politics of place", in Democracy and Vision: Sheldon Wolin and the Vicissitudes of the Political Eds A Botwinick, W E Connolly (Princeton University Press, Princeton, NJ) pp 256-289

Foucault M, 1977 Discipline and Punish: The Birth of the Prison translated by A Sheridan (Vintage Books, New York)

Foucault M, 1980 Power/Knowledge: Selected Interviews and Other Writings 1972 - 1977 Ed. C Gordon, translated by C Gordon, L Marshall, J Mepham, K Soper (Pantheon Books, New York)

Gottmann J, 1980, "Confronting centre and periphery", in Centre and Periphery: Spatial Variation in Politics Ed. J Gottmann (Sage, London) pp 11-25 
Hegel G W F, 1977 Phenomenology of Spirit translated by A V Miller (Clarendon Press, Oxford); first published in 1807

Honig B, 1993 Political Theory and the Displacement of Politics (Cornell University Press, Ithaca, NY)

Isin E, 2002 Being Political: Genealogies of Citizenship (University of Minnesota Press, Minneapolis, $\mathrm{MN}$ )

Johnston R, 2001, "Out of the 'moribund backwater': territory and territoriality in political geography" Political Geography $20677-693$

Keith M, 1997, "Street sensibility? Negotiating the political by articulating the spatial", in The Urbanization of Injustice Eds A Merrifield, E Swyngedouw (New York University Press, New York) pp $137-160$

Kohn M, 2003 Radical Space: Building the House of the People (Cornell University Press, Ithaca, NY)

Laclau E, 1990 New Reflections on the Revolution of our Time (Verso, London)

Laclau E, Mouffe C, 1985 Hegemony and Socialist Strategy: Towards a Radical Democratic Politics (Verso, London)

Lacoue-Labarthe P, Nancy J-L, 1997 Retreating the Political Ed. S Sparks (Routledge, London)

Lefort C, 1988 Democracy and Political Theory translated by D Macey (University of Minnesota Press, Minneapolis, MN)

Le Monde 2002, "Le ministre veut publier plus fréquemment les chiffres de la délinquance" [The minister wants to publish figures of delinquency more frequently], 31 May

Levitas R, 1996, "The concept of social exclusion and the new Durkheimian hegemony" Critical Social Policy 16(1) $5-20$

Massey D, 1993, "Politics and space/time", in Place and the Politics of Identity Eds M Keith, S Pile (Routledge, London) pp $141-161$

Massey D, 1995, “Thinking radical democracy spatially" Environment and Planning D: Society and Space $13283-288$

Massey D, 1999, "Spaces of politics”, in Human Geography Today Eds D Massey, J Allen, P Sarre (Polity Press, Cambridge) pp 279-294

Mouffe C, 1995, "Post-Marxism: democracy and identity" Environment and Planning D: Society and Space $13259-265$

Nancy J-L, 1988 L'Expérience de la Liberté [The experience of freedom] (Galilée, Paris)

Nancy J-L, 1991 The Inoperative Community Ed. P Connor, translated by P Connor, L Garbus,

M Holland, S Sawhney (University of Minnesota Press, Minneapolis, MN)

Nancy J-L, 2001 Le Sens du Monde [Sense of the world] revised edition (Galilée, Paris)

Percy-Smith J, 2000, "Introduction: the contours of social exclusion", in Policy Responses to Social Exclusion: Towards Inclusion? Ed. J Percy-Smith (Open University Press, Milton Keynes, Bucks) pp $1-21$

Pile S, Keith M (Eds), 1997 Geographies of Resistance (Routledge, London)

Rancière J, 1994, "Post-democracy, politics and philosophy: an interview with Jacques Rancière" Angelaki 1(3) 171 - 178

Rancière J, 1995a, "Politics, identification, and subjectivization", in The Identity in Question Ed. J Rajchman (Routledge, New York) pp 63-70

Rancière J, 1995b On the Shores of Politics translated by L Heron (Verso, London)

Rancière J, 1995c La Mésentente: Politique et Philosophie [Dis-agreement: politics and philosophy] (Galilée, Paris)

Rancière J, 1997, "Democracy means equality" Radical Philosophy 82 (March/April) 29-36

Rancière J, 1998 Aux Bords du Politique [On the shores of politics] revised edition (La Fabrique, Paris)

Rancière J, 1999 Dis-agreement: Politics and Philosophy translated by J Rose (University of Minnesota Press, Minneapolis, MN)

Rancière J, 2000a Le Partage du Sensible: Esthétique et Politique [The partition of the sensible: aesthetics and politics] (La Fabrique, Paris)

Rancière J, 2000b, "Literature, politics, aesthetics: approaches to democratic disagreement" SubStance 92 3-24

Rancière J, 2000c, "Dissenting words: a conversation with Jacques Rancière" diacritics 30(2) $113-126$

Rancière J, 2001, “Ten theses on politics” Theory and Event 5(3), http://muse.jhu.edu/journals/ theory_and_event/toc/archive.html\#5.3

Rey A (Ed.), 1976 Le Petit Robert (Dictionnaires Robert, Paris) 
Shapiro M, 2002, "Time, disjuncture, and democratic citizenship", in Democracy and Vision:

Sheldon Wolin and the Vicissitudes of the Political Eds A Botwinick, W E Connolly (Princeton University Press, Princeton, NJ) pp $232-255$

Shapiro M, Neubauer D, 1989, "Spatiality and policy discourse: reading the global city" Alternatives $14301-325$

Slater D, 2002, "Other domains of democratic theory: space, power, and the politics of democratization" Environment and Planning D: Society and Space $20255-276$

Walker, R B J, 1993 Inside/Outside: International Relations as Political Theory (Cambridge University Press, Cambridge)

Wolin S, 1960 Politics and Vision: Continuity and Innovation in Western Political Thought (Little, Brown, Boston, MA)

Žižk S, 1991 For They Know Not What They Do: Enjoyment as a Political Factor (Verso, London) 